\title{
STRATEGI IBU RUMAH TANGGA PENENUN KAIN SARUNG MUNA DALAM UPAYA MENINGKATKAN PENDAPATAN RUMAH TANGGA DI DESA LAPOLEA KECAMATAN BARANGKA KABUPATEN MUNA BARAT
}

\author{
Efendi $^{1}$, Darmin Tuwu' ${ }^{2}$, Tanzil ${ }^{3}$ \\ ${ }^{123}$ Jurusan Ilmu Kesejahteraan Sosial FISIP Universitas Halu Oleo, fandhyfisip@gmail.com \\ darmintuwu@gmail.com
}

\begin{abstract}
This study aims to describe the strategy of weaving housewives in an effort to increase family income in Lapolea Village, Barangka District, West Muna Regency. This type of research is a qualitative descriptive study, which describes the objective conditions of the field in accordance with the research objectives. Data collection techniques through observation, interviews and documentation, with 13 informants. The results showed that the weaver women were housewives who helped their husbands to supplement household incomes. The strategies used in an effort to increase household income are: First, Verified work, this strategy is carried out if the results obtained are uncertain or the uncertainty of the results obtained. Therefore weaving mothers combine work to obtain additional income to meet household needs such as gardening and to become street vendors. Second, the role of children as household members is very large in increasing family income. Third, social networking is one of the strategies in dealing with poverty by utilizing the surrounding community. This social network is what weavers do to meet the shortcomings they face by way of debt, such as debt to family, neighbors, suppliers of raw materials and business friends. Finally, Arisan is one of the strategies undertaken by weavers to raise capital for the development of woven businesses and to anticipate unexpected family needs.
\end{abstract}

\begin{abstract}
ABSTRAK
Penelitian ini bertujuan untuk mendeskripsikan strategi ibu rumah tangga penenun dalam upaya meningkatkan pendapatan keluarga di Desa Lapolea Kecamatan Barangka Kabupaten Muna Barat. Jenis Penelitian adalah penelitian deskriptif kualitatif, yaitu mendeskripsikan kondisi objektif lapangan sesuai dengan tujuan penelitian. Teknik pengumpulan data melalui observasi, wawancara serta dokumentasi, dengan informan sebanyak 13 orang. Hasil penelitian menunjukan bahwa para wanita penenun adalah ibu rumah tangga yang membantu suami untuk menambah penghasilan rumah tangga. Strategi yang digunakan dalam upaya meningkatkan pendapatan rumah tangga adalah: Pertama, Diverifikasi pekerjaan, strategi ini dilakukan apabila hasil yang diperoleh tidak menentu atau ketidak-pastian hasil yang diperoleh. Oleh sebab itu para ibu penenun melakukan pengkombinasian pekerjaan guna memperoleh penghasilan tambahan untuk mencukupi kebutuhan rumah tangga seperti berkebun dan menjadi penjual gorengan keliling. Kedua, Peran anak sebagai anggota rumah tangga sangat besar dalam menambah penghasilan keluarga. Ketiga, Jaringan sosial merupakan salah satu strategi dalam menghadapi kemiskinan dengan cara memanfaatkan masyarakat sekitarnya. Jaringan sosial inilah yang dilakukan ibu penenun guna mencukupi kekurangan yang dihadapinya dengan cara berhutang seperti berhutang kepada keluarga, tetangga, penyedia bahan baku dan teman bisnis. Terakhir, Arisan merupakan salah satu strategi yang dilakukan oleh ibu-ibu penenun guna mengumpulkan modal demi pengembangan usaha tenunan serta mengantisipasi kebutuhan keluarga yang tidak terduga.
\end{abstract}

Key Words: Strategi Ibu Rumah Tangga Penenun, Peningkatan Pendapatan .

\section{PENDAHULUAN}

Kemajuan zaman sering diiringi dengan perkembangan informasi dan tingkat kemampuan intelektual manusia. Bersama itu peran perempuan dalam kehidupan pun terus berubah untuk menjawab tantangan zaman, tak terkecuali mengenai peran perempuan dalam meningkatkan pendapatan keluarga. Biasanya tulang punggung kehidupan keluarga adalah pria atau suami. Tapi kini para perempuan banyak yang berperan aktif untuk mendukung ekonomi keluarga. Sudah menjadi fenomena yang umum bahwa banyak dari ibu rumah tangga yang bekerja di luar rumah baik sebagai pekerja di perusahaan Negara maupun swasta, lembaga-lembaga Negara maupun 
wirausaha mandiri. Namun yang menyebabkan para ibu rumah tangga ini bekerja, diantaranya suami tidak mencari nafkah dikarenakan sakit parah, atau meninggal dunia, pendapatan suami yang tidak dapat mencukupi untuk kebutuhan keluarga, bekerja sejak sebelum menikah, serta ingin mengembangkan potensi yang dimilikinya.

Seorang ibu mempunyai peranan yang penting dalam kehidupan suatu keluarga, baik peranannya bagi suami maupun anaknya. Di dalam kehidupan rumah tangga, seorang ibu berkewajiban untuk melayani suami dan anaknya dalam semua aspek yang ada dalam kehidupan keluarganya. Kewajiban seorang ibu tidak hanya berbelanja, memasak, mencuci, berdandan, mengatur keuangan, dan melahirkan, serta merawat anak, akan tetapi seorang ibu mempunyai peran yang lebih dominan dalam kehidupan suatu keluarga dibandingkan dengan peran suami (Pujosuwarno, 1994:44).

Kabupaten Muna Barat tidak saja dikenal sebagai penghasil pertanian yang melimpah tetapi dikenal juga sebagai penghasil kain sarung muna yang mencerminkan kebanggaan masyarakat tentang hasil karya budaya mereka. Menenun sarung bagi orang-orang Muna di Sulawesi Tenggara sudah kebiasaan atau tradisi yang diwariskan turun temurun, biasanya kaum wanita yang melakukan aktivitas ini, anak-anak remaja, gadis, hingga perempuan dewasa menenun untaian benang yang kemudian digambungkan hingga menjadi satu kain berukuran besar yang dapat dijahit dan dijadikan sarung.

Begitu juga yang terjadi pada masyarakat Desa Lapolea Kecamatan Barangka Kabupaten Muna barat. Masyarakat yang tingkat ekonominya masih sangat sederhana dengan profesi beraneka ragam. Sebagian besar masyarakat Desa Lapolea merupakan pengrajin sarung tenun muna, adapun jumlah penenun yang ada didesa lapolea sebanyak 180 orang. Khususnya para ibu rumah tangga. Mereka menenun sarung adat muna, secara berkelanjutan sesuai ada atau tidaknya pesanan, namun ada pula yang menjualnya dipasar atau kepada para pengumpul atau penanda. Selain sebagai penenun ibu rumah tangga juga bekerja sebagai petani. Tanaman yang mereka tanam bermacammacam, mulai dari jambu mente, tanaman sayur-sayuran, dan tanaman yang dapat dijadikan sebagai kebutuhan pokok seperti jagung dan ubi kayu. Dalam sistem kerja ibu rumah tangga mempunyai pembagian waktu dalam mengurus rumah tangga dan dan bekerja menenun kain sarung. Selesai mengurus rumah tangga mereka lanjut dalam pembuatan sarung. Pembuatan satu lembar kain sarung tersebut membutuhkan modal sebanyak Rp. 50.000 dan menenunan satu kain sarung tersebut bisa terselesaikan dalam jangka waktu 3-4 hari. Dalam sebulan itu mereka berhasil menghasilkan 67 lembar kain sarung muna. Meskipun mereka bekerja dengan cara duduk, sehingga bisa dikatakan bahwa mereka duduk selama kurang 12 jam sehari untuk menenun sarung tersebut.

Ibu rumah tangga penenun yang ada di Desa Lapolea mereka bekerja bukan hanya disebabkan karena kurangnya pendapatan suami dalam biaya kehidupan keluarga, akan tetapi mereka pada umumnya bekerja sebagai petani dan berjualan di pasar. Mereka berperan dalam upaya membantu perekonomian keluarga dengan cara membuat usaha kain sarung muna. Ibu rumah tangga ini menganggap bahwa mereka dapat meringankan beban suami dalam hal ekonomi melalui usaha tanpa meninggalkan kewajibannya sebagai pengurus rumah tangga. Walaupun Para ibu rumah tangga ini membantu perekonomian keluarga tetapi mereka selalu membagi waktu untuk anak dan keluarganya. Karena pada dasarnya mereka dituntut untuk tetap mengurus rumah 
tangga, dan juga membantu perekonomian keluarga untuk pemenuhan kebuhan dasar keluarga. Hal itu mereka lakukan untuk mencapai suatu keluarga yang sejahtera.

Sehingga melihat fenomena diatas peneliti ingin melakukan penelitian mendalam mengenai Strategi Ibu Rumah Tangga Penenun Kain Sarung Muna (kamooru) Dalam Upaya Meningkatkan Pendapatan Keluarga di Desa Lapolea, Kecamatan Barangka, Kabupaten Muna Barat.

Ada berbagai istilah strategi yang diungkapkan oleh berbagai para ahli.. Istilah strategi sudah menjadi istilah yang sering digunakan oleh masyarakat untuk menggambarkan berbagai makna seperti suatu rencana, taktik atau cara untuk mencapai apa yang diinginkan. Strategi pada hakikatnya adalah perencanaan (planning) dan manajemen (management) untuk mencapai suatu tujuan. Tetapi, untuk mencapai tujuan tersebut, strategi tidak berfungsi sebagai peta jalan yang hanya menunjukkan arah saja, melainkan harus mampu menunjukkan bagaimana taktik operasionalnya (Effendy, 2007:32).

Jika dilihat dari konsepnya, strategi dapat diartikan sebagai rencana yang cermat mengenai suatu kegiatan untuk mencapai tujuan tertentu. Secara harfiah pengertian strategi adalah berbagai kombinasi dari aktivitas dan pilihan-pilihan yang harus dilakukan orang agar supaya dapat mencapai kebutuhan dan tujuan kehidupannya. Konsep strategi ini merupakan bagian dari pilihan rasional, dimana dalam teori tersebut dikatakan bahwa setiap pilihan yang dibuat individu, termasuk pemilihan suatu strategi dibuat berdasarkan perimbangan rasional dengan mempertimbangkan untung rugi yang akan diperoleh (Mugni, 2006:34).

Menurut Edi Suharto (2009) menyatakan strategi bertahan hidup dalam mengatasi goncangan dan tekanan ekonomi dapat dilakukan dengan berbagai cara. Cara-cara tersebut dapat dikelompokan menjadi tiga kategori yaitu:

\section{Strategi Aktif}

Strategi aktif merupakan strategi bertahan hidup yang dilakukan dengan cara memanfaatkan segala potensi yang dimiliki. Menurut Suharto (2009) strategi aktif merupakan strategi yang dilakukan keluarga miskin dengan cara mengoptimalkan segala potensi keluarga (misalnya melakukan aktivitasnya sendiri, memperpanjang jam kerja dan melakukan apapun demi menambah penghasilannya). Berdasarkan uraian di atas dapat disimpulkan bahwa yang dimaksud strategi aktif adalah strategi pemenuhan kebutuhan hidup yang dilakukan seseorang atau keluarga dengan cara memakmalkan segala sumber daya dan potensi yang dimiliki keluarga mereka.

\section{Strategi Pasif}

Strategi pasif merupakan strategi bertahan hidup yang dilakukan dengan cara meminimalisir pengeluaran keluarga sebagaimana pendapat Suharto (2009) yang menyatakan bahwa strategi pasif adalah strategi bertahan hidup dengan cara mengurangi pengeluaran keluarga (misalnya biaya untuk sandang, pangan, pendidikan, dan sebagainya).

\section{Strategi Jaringan}

Strategi jaringan adalah strategi yang dilakukan dengan cara memanfaatkan jaringan sosial. Menurut Suharto (2009) strategi jaringan merupakan strategi bertahan hidup yang dilakukan dengan cara menjalin relasi, baik formal maupun dengan lingkungan sosialnya dan lingkungan 
kelembagaan (misalnya meminjam uang kepada tetangga, mengutang di warung atau toko, memanfaatkan program kemiskinan, meminjam uang ke rentenir atau bank dan sebagainya).

Sedangkan menurut Kristianti (2014) berpendapat bahwa penggolongan strategi bertahan hidup dalam dua sektor, yaitu: strategi ekonomi serta sosial. Pada masyarakat strategi ekonomi dilakukan dengan cara:

1. Memberdayakan seluruh anggota keluarga untuk menjaga kelangsungan perekonomian rumah tangga,

2. Diversifikasi pekerjaan dengan tidak hanya memiliki satu tumpuan mata pencaharian,

3. Menekan pengeluaran

4. Hutang piutang, dengan meminjam uang tetangga atau saudara ketika kesulitan karena tidak ada bunga.

Sedangkan dalam strategi sosial ditempuh dengan beberapa cara seperti:

1. Hubungan patron-klien antara penjual dan pembeli,

2. Arisan untuk menghimpun dana tak terduga untuk menjadi simpanan dan bantuan ketika membutuhkan dana.

Sedangkan menurut Kusnadi (2000), strategi keluarga miskin dalam upaya meningkatkan pendapatan dapat dilakukan melalui:

1. Deverifikasi Pekerjaan

Straegi adaptasi yang digunakan oleh para keluarga miskin untuk menghadapi ketidak pastian penghasilan adalah kombinasikan pekerjaan. Diverifikasi usaha akan terjadi apabila hasil yang diperoleh tidak pasti / ketidak pastian hasil yang diperoleh

2. Peranan Anggota Keluarga

Dalam upaya memenuhi kebutuhan dasar kehidupan, isu substansi yang selalu dihadapi oleh keluarga atau rumah tangga adalah bagaimana individu-individu yang ada didalamnya harus berusa maksimalkan dan bekeja sama untuk memenuhi kebutuhan rumah tangga sehingga kelangsungan hidupnya dapat terpelihara. Setiap anggota rumah tangga bisa memasuki baragam pekerjaan yang dapat diakses sehingga memperoleh penghasilan yang berfungsi untuk menjaga kelangsungan hidup bersama.

3. Jaringan Sosial

Melalui jaringan sosial, individu-idividu rumah tangga akan lebih efektif dan efisien untuk mencapai atau emperoleh akses terhadap sumber daya yang tersedia di lingkungan. Jaringan sosial itu berfungsi sebagai salah satu strategi adaptasi dalam konteks mengatasi kesulitan ekonomi untuk memenuhi kebutuhan hidup sehari-hari.

4. Migrasi

Migrasi ini dilakukan ketika di daerah tempat pencarian nafkah tersebut tidak dapat memiliki penghasilan ataupun sedikit pengahasilan yang didapatkan. Sehingga mereka pergi bergabung kesuatu tempat yang bisa memiliki pendapatan yang banyak. Migrasi adalah salah satu cara untuk memperoleh penghasilan yang tinggi agar kebutuhan hidup keluarga bisa terjamin. 
Strategi pemenuhan kebutuhan hidup keluarga menurut Fatimah (2016), adalah suatu tindakan yang dilakukan oleh setiap orang untuk dapat mempertahankan kelangsungan hidupnya dan hidup keluarganya melalui pekerjaan yang dilakukannya. Strategi bertahan hidup atau yang biasa disebut Coping Strategies dapat dipahami sebagai cara untuk mengatasi kesulitan dalam hidup. Melalui strategi ini seseorang dapat berusaha untuk menambah penghasilan lewat pemanfaatan sumber-sumber lain ataupun mengurangi pengeluaran kuantitas dan kualitas barang dan jasa. Cara-cara individu dalam menyusun strategi dipengaruhi oleh posisi individu atau kelompok dalam struktur masyarakat, sistem kepercayaan dan jaringan sosial yang dipilih, termasuk keahlian dalam memobilisasi sumber daya yang ada, tingkat keterampilan, kepemilikan aset, jenis pekerjaan dan motivasi pribadi.

Munculnya suatu strategi ibu rumah tangga dimana berawal dari masalah sosial. Yang dimana masalah sosial tersebut berhubungan dengan kelangsungan hidup anggota keluarga. Adapun salah satu masalah sosia yaitu kemiskinan. Kemiskinan merupan salah satu masalah sosial yang sangat kompleks karena menyangkut berbagai aspek kehidupan seperti hak untuk terpenuhinya kebutuhan pangan, sandang, kesehatan, pendidikan, pekerjaan, dan lain-lain.

Berbicara tentang kemiskinan ada berbagai banyak definisi tentang kemiskinan yang diungkapkan oleh para ahli. Menurut Chambers (1987:8-9) bahwa kemiskinan berkaitan dengan suatu keadaan melarat dan ketidakberuntungan, minimnya pendapatan dan harta, kelemahan fisik, isolasi, kerapuhan serta ketidak berdayaan. Sedangkan menurut Suharto (2005:132) ciri kemiskinan yaitu sebagai berikut: Ketidakmampuan memenuhi kebutuhan konsumsi dasar (pangan, sandang dan papan), ketiadaan akses terhadap kebutuhan hidup dasar lainnya (kesehatan, pendidikan, sanitasi, air bersih dan transportasi), ketiadaan jaminan masa depan (karena tiadanya investasi untuk pendidikan dan keluarga), kerentanan terhadap goncangan yang bersifat individual maupun missal, rendahnya SDM dan keterbatasan SDA, ketidakterlibatan dalam kegiatan sosial masyarakat, ketiadaan akses terhadap lapangan kerja dan mata pencaharian yang berkesinambungan, ketidakmampuan untuk berusaha karena kecacatan fisik maupun mental, dan ketidakmampuan dan ketidakberuntungan sosial (anak terlantar, wanita korban tindak kekerasan rumah tangga, janda miskin, kelompok marjinal dan terpencil).

Menurut Friedman (2004), kemiskinan juga berarti ketidaksamaan kesempatan untuk mengakumulasikan basis kekuasaan sosial. Basis kekuasaan sosial ini meliputi modal produktif seperti tanah, alat produksi, perumahan, kesehatan. sumber keuangan, organisasi sosial dan politik yang dapat digunakan untuk kepentingan bersama seperti koperasi, partai potitik, organisasi sosial, jaringan sosial, pengetahuan dan keterampilan, serta informasi yang berguna untuk kemajuan hidup. Persoalan kemiskinan tidak hanya terkait dengan materi (ekonomi dan fisik-materil) sebagaimana pandangan kaum matrealistik, tetapi lebih daripada itu kemiskinan juga berkaitan dengan persoalan mulitidimensional tidak hanya mencakup aspek ekonomi, tetapi juga aspek sosial, budaya dan lingkungan (Myrdal, 1968; Sen, 2001).

\section{METODE PENELITIAN}

Penelitian ini akan dilaksanakan di Desa Lapolea Kecamatan Barangka Kabupaten Muna Barat. Adapun alasan peneliti mengambil objek penelitian di Desa Lapolea Kecamatan Barangka 
Kabupaten Muna Barat ialah desa tersebut masih banyak penenun dan bahkan menjadi salah satu mata pencaharian mereka.

Jenis penelitian ini adalah salah satu jenis penelitian yang dilakukan dengan pendekatan deskriptif kualitatif yaitu penelitian dengan memberikan mengenai fenomena-fenomena yang terjadi selama penelitian yang mengenai strategi ibu rumah tangga penenun kain sarung muna dalam upaya meningkatkan pendapatan keluarga di Desa Lapolea Kecamatan Barangka Kabupaten Muna Barat.

Penelitian ini menggunakan teknik pemilihan informasi secara non probability sampling (pengambilan sampel tidak berdasarkan peluang). Sugiyono (2005) mengatakan bahwa non probability sampling merupakan teknik pengambilan sampel yang tidak memberikan peluang/kesempatan yang sama bagi setiap unsur anggota populasi untuk dipilih menjadi sampel. Dalam penentuan informan ini, peneliti menggunakan teknik purposive sampling (disengaja), dimana peneliti menggunakan penilaian sendiri dalam memilih sampel. Neuman (2007) mengatakan bahwa purposive sampling diguanakan peneliti dimana ia memiliki pertimbangan dalam memilih kasus dengan tujuan tetentu. Teknik ini dipilih atas dasar agar data yang diperoleh adalah data yang akurat karena sampel merupakan sumber data informasi yang tepat untuk dibutuhkan oleh peneliti. Adapun jumlah informan yang diambil pada penelitian ini sebanyak 13 orang, terdiri dari informan kunci sebanyak $11 \mathrm{ibu}$ rumah tangga penenun, serta beberapa informan pendukung diantaranya kepala desa dan tokoh masyarakat 1 orang.

Dalam penelitian ini, peneliti menggunakan beberapa metode untuk mengumpulkan data yang mana hal tersebut diharapkan saling melengkapi dan meyempurnakan data yang satu dengan yang lain. Berikut beberapa metode yang digunakan peneliti:

Metode observasi adalah metode pengumpulan data dengan pengamatan dan pencatatan yang sistematis atas fenomena-fenomena yang diteliti Hadi, (2004). Dalam metode ini melakukan secara langsung untuk mengamati lingkungan Desa Lapolea seperti letak geografis, jumlah ibu penenun, struktur organisasi, sarana dan prasarana Desa Lapolea, dan mengamati strategi ibu rumah tangga penenun dalam upaya meningkatkan pendapatan keluarga.

Metode Wawancara yaitu metode pengumpulan data tanya jawab yang sepihak dikerjakan dengan sistematis dan berlandaskan kepada tujuan peneliti (Hadi, 2004). Jenis wawancara yang penulis gunakan adalah wawancara bebas terpimpin, dimana pelaksanaan wawancara menggunakan kerangka pertanyaan yang akan ditanyakan kepada informan.

Metode dokumentasi adalah metode pengumpilan data dengan mencari data yang mengenai hal-hal atau variable yang berupa catatan, dokumen, notulen rapat, agenda (Arikunto, 2006). Metode ini peneliti menggunakan metode dokumentasi untuk memeperoleh data yang berupa buku induk, catatan, arsip, sehingga dapat diperoleh data tentang gambaran dan keadaan Desa Lapolea.

\section{PEMBAHASAN}

Strategi Ibu Rumah Tangga Penenun Kain Sarung Muna dalam Upaya Meningkatkan Pendapatan Keluarga (Studi Ibu Rumah Tangga di Desa Lapolea Kecamatan Barangka Kabupaten Muna Barat) 
Strategi yang dilakukan oleh ibu penenun ialah salah satu upaya dalam meningkatkan pendapatan keluarga mereka. Kemiskinan pada rumah tangga penenun menurut hasil penelitian disebabkan karena pendapatan suami yang diperoleh dari hasil menjadi petani tidaklah mencukupi kebutuhan hidupnya. Rata-rata hasil suami penenun yang diperoleh dalam berbagai pekerjaan sehari sebesar Rp. 20.000 sampai Rp. 50.000. Hasil dari pekerjaan menjadi seorang penenun pun tidak dapat diprediksi, semua tergantung dari hasil tenunan yang diperoleh. Oleh karena itu strategi yang dilakukan oleh ibu rumah tangga penenun dalam mengatasi kemiskinan yang didasari dengan banyaknya kebutuhan keluarga. Adapun strategi yang dilakukan antara lain:

\section{Diverifikasi Usaha}

Penenun dan penada mereka sama-sama mengalami ketidak pastian dalam memperoleh pendapatan. Pendapatan yang mereka peroleh juga sama-sama dari hasil tenunan yang diperoleh ibu penenun. Oleh sebab itu para ibu penenun harus dapat terus berusaha untuk bisa memperoleh penghasilan guna memenuhi kebutuhan keluarganya.

Diverifikasi usaha akan terjadi apabila hasil yang diperoleh tidak pasti / ketidak pastian hasil yang diperoleh. Oleh sebab itu para ibu rumah tangga mengkombinasi pekerjaan guna memperoleh tambahan penghasilan yang berguna untuk mencukupi kebutuhan keluarganya. Pekerjaan menjadi menenun bukanlah pekerjaan yang mudah dan mendapat penghasilan yang melimpah. Pekerjaan menjadi penenun merupakan pekerjaan yang banyak menguras waktu ketika ia tidak paham dari bagian-bagian untuk menenun maka gagalah tenunan tersebut dan pekerjaan menenun penghasilannya tidak pasti. Ketidakpastian penghasilan yang diperoleh ibu penenun menjadikan harus mempunyai pekerjaan lain selain menjadi penenun. Penghasilan menenun yang hanya cukup untuk memenuhi kebutuhan sekunder saja menjadikan penenun harus lebih giat bekerja. Sehingga untuk dapat memenuhi kebutuhan keluarga para penenun melakukan beberapa pekerjaan sampingan selain menenun. Hal ini terungkap dari pengakuan informan yang bernama ibu Wa Sarni 36 tahun, mengatakan bahwa:

"Kalau cuman mengandalkan pendapatan dari hasil menenun jelas tidak akan cukup untuk memenuhi semua kebutuhan keluarga. Sedangkan hasil menjadi penenun hanya cukup untuk kebutuhan yang dibutuhkan dalam rumah saja. Oleh sebab itu saya mencari pekerjaan lain selain menenun. Adapun usaha yang saya lakukan untuk menambah penghasilan ya berkebun dan menjadi buruh tani, kalau ada yang membutuhkan bantuan tenaga saya, sedangkan menjadi petani merupakan pekerjaan yang saya lakukan apabila tidak ada bahan. Hal ini saya lakukan semata-mata untuk mencukupi kebutuhan keluarga saya.”( Tanggal 20 April 2018).

Dari hasil wawancara di atas dapat disimpulkan bahwa poin yang terpenting dalam suatu kelurga yaitu pemenuhan kebutuhan anggota keluarga. Untuk memenuhi kebutuhan keluarga tersebut harus memiliki pendapatan lebih, dengan cara tidak bertumpuan pada satu pekerjaan tetapi harus mencari peluang untuk mencari pekerjaan lain untuk mendapatkan pendapatan tambahan. Pernyataan tersebut senada dengan seorang informan yang bernama ibu Hayati 35 tahun, mengatakan bahwa:

"Saya selaku penenun buruh yang jumlah pendapatan tidak seberapa dan kadang kebutuhan sekunder rumahtangga pun belum bisa tercukupi sehingga saya harus bekerja sambilan pas tidak menenun. Saya bekerja juga sebagai penjual gorengan keliling serta menjual roti di 
daerah sini saja, itung-itung buat tambah-tambah pemasukan dan memenuhi kebutuhan keluarganya."( Tanggal 20 April 2018).

Pernyataan-pernyataan tersebut juga didukung dengan hasil pengamatan peneliti. Dari hasil pengamatan peneliti, ibu penun bekerja ke ladang setelah menenun, akan tetapi hal ini tidak terjadi setiap waktu. Lebih sering ibu penenun ke ladang pada saat tidak menenun dikarenakan tidak ada bahan dan ada pekerjaan yang harus dikerjakan bersama-sama. Selain menjadi petani, terdapat beberapa ibu penenun yang menjadi penjual gorengan keliling. Hal itu juga dilakukan ketika mereka tidak menenun karena berbagai faktor yang menjadi hambatan dalam menenun. Diversifikasi pekerjaan yang dilakukan oleh para ibu penenun guna menambah penghasilannya yang berfungsi dalam pemenuhan kebutuhan keluarganya yaitu ibu penenenun melakukan pekerjaan sampingan, misalnya bagi ibu rumah tangga yang punya ladang mereka mempunyai pekerjaan sampingan sebagai petani. Biasanya petani menanam tanaman seperti jagung, ubi kayu dan pisang. Petani memilih untuk menanam tanaman seperti itu dikarenakan tanaman tersebut cocok ditanam pada kultur tanah yang sangat berpotensi seperti tanah di Desa Lapolea. Hasil yang diperoleh dari sektor pertanian pun dirasa sangat menguntungkan, dengan satu petak tanah sekali panen jagung mereka bisa untung sebanyak 2-4 juta. Hasil tersebut sangat membantu keluarga penenun dalam mencukupi kebutuhannya dan paling tidak mendapat pemasukan ketika tidak bisa menenun. Profesi lain yang dilakukan para ibu penenun ialah sebagai penjual gorengan keliling.

Menjadi penjual gorengan keliling merupakan salah satu cara yang dilakukan para ibu penenun yang tidak memiliki potensi untuk berladang. Meski menjadi pedagang keliling hasil yang di dapatkan tidak seberapa akan tetapi hasil yang diperoleh setidaknya bisa membantu mencukupi kebutuhan keluarganya dan mengeluarkan rumah tangga penenun dari derita kemiskinan.

\section{Peran Anggota Keluarga}

Kurangnya penghasilan yang dihasilkan ibu penenun sebagai pembantu pencari nafkah dalam mencukupi kebutuhan keluarganya menjadikan anggota keluarga yang lain juga ikut membantu keuangan untuk keluargana dengan cara bekerja. Menurut hasil penelitian, mereka mempunyai pekerjaan yang beragam. Terdapat jenis-jenis pekerjaan yang dilakukan suami penenun untuk berusaha memenuhi kebutuhan keluarganya, jenis pekerjaan yang dilakukan meliputi: 1) membantu mengantarkan hasil tenunan yang sudah selesai 2) bekerja sebagai buruh mebel, 3) bekerja sebagai pekerja banguna, dan 4) bekerja sebagai petani.

Berdasarkan pengamatan peneliti beberapa suami penenun ada yang bekerja sebagai buruh mebel, sebagai tukang batu. Beberapa lainnya bertani dengan berbagai tanaman yang ditanam ada jagunng, ubi kayu dan pisang. Walaupun mereka tidak semuanya membantu akan tetapi mereka bekerja guna membantu mencukupi kebutuhan keluarganya. Seperti yang diungkapkan oleh seorang informan dari suami penenun yang bapak La Ode Puke 40 tahun, menyatakan bahwa:

"Saya disini bekerja berbagai macam pekerjaan kadang bekerja sebagai buruh mebel, terkadang saya bekerja tenaga panggilan ketika ada masyarakat lainnnya mencari tenaga untuk mengerjakan sesuatu seperti panen ubi maka kami digaji perhari. Yang saya kerjakan berdasarkan pada kelebihan yang saya miliki. Pendapatan yang saya dapat juga lumayan dan yang penting bisa membantu memenuhi kebutuhan keluarga.”( Tanggal 23 April 2018). 
Dari hasil wawancara di atas dapat disimpulkan bahwa peran seorang laki-laki sangat dibutuhkan dalam sebuah keluarga yang harmonis terutama dalam peran mencari nafkah untuk memenuhi kebutuhan anggota keluarganya. Penjelasan terebut senada dengan salah satu informan yang salah satu suami penenun yang bernama bapak La Tinda, menyatakan bahwa:

"Penghasilan yang diperoleh dari menenun tidak menentu, oleh karena itu saya bekerja untuk mengusahakan bagaimana supaya mencukupi kebutuhan keluarga. Jadi apapun yang dikerjakan istri sya pasti harus ikut serta didalam. Seperti ketika sedang menenun maka saya kadang mencari bahan untuk perlengkapannya, dan mengantar tenunan ketika ada tenunan yang sudah jadi, dan saya bekerja serabutan kadang kalau ada bangunan yang dikerja maka saya ikut harian di bangunan tersebut, dan kadang juga ketika warga lain mencari anggota untuk mengerjakan seseuatu maka saya ikut serta dalam pekerjaan tersebut. Hasil yang diperoleh sangat membantu untuk mencukpi kebutuhan keluarga saya."(tanggal 23 April 2018).

Kebutuhan yang harus dapat dipenuhi juga banyak yang melibatkan anak-anak mereka bekerja untuk dapat meringankan beban orang tuanya. Anak-anak yang usia dewasa setelah mereka semasih SMP atau sudah lulus SMA mereka dianjurkan bekerja oleh orang tuanya. Mereka beranggapan bahwa dengan bekerja biaya untuk pendidikan anak tidak dipikirkan lagi, dan anakanak mereka sudah tidak terlalu menjadi beban kedua orang tuanya. Anak-anak mereka pun beranggapan bahwa dengan bekerja mereka bisa membantu mencukupi kebutuhan keluarga mereka dan meringankan beban orangtua mereka. Seperti yang diungkapkan oleh salah satu anak dari penenunyang bernama Wa Rini 18 tahun, menyatakan bahwa:

"Saya sejak SMP saya sudah bekerja sebagai penenun, ketika saya sesudah dari sekolah dan sudah makan maka saya langsung membantu ibu untuk menenun. Dengan adanya campur tangan kami maka beban ibu berkurang dan hasil dari menenun juga banyak. Kehidupan kami juga tergolong pas-pasan, oleh sebab itu saya bekerja untuk membantu kehidupan keluarga saya.”( Tanggal 17 April 2018).

Dari hasil wawancara di atas dapat disimpulakan bahwa suatu pendidikan memang sangat penting bagi anak-anak tetapi sebuah pendidikan tidak bisa tercapai tanpa ada dukungan suatu ekonomi. Pendapat tersebut diperkuat dengan pendapat seorang anak penenun yang bernama $\mathrm{W}$ Arni 20 tahun, menyatakan bahwa:

"Setelah saya lulus sekolah SMA, saya tidak melanjutkan sekolah meski dalam hati saya ada keinginan besar untuk dapat kuliah, saya juga tau biaya kuliah itu mahal dan saya tidak mau menambah beban orangtua saya, oleh karna itu saya lebih baik bekerja sebagai penenun dan penjual gorengan keliling, ya meskipun hanya sebagai penenun dan penjual keliling tapi setidaknya saya meringankan beban orangtua saya dan dapat membantu dalam mencukupi kebutuhan di dalam keluarga saya.”( Tanggal 17 April 2018).

Bentuk pekerjaan dan anak dalam memperoleh tambahan penghasilan guna mencukupi kebutuhannya antara lain, bentuk pekerjaan suami dari penenun: ikut serta dalam pekerjaan istri yang di lakukan, bekerja buruh mebel, bekerja sebagai tukang dan bekerja sebagai petani. Sedangkan bentuk usaha yang dilakukan anak penenun terutama anak yang sudah dewasa ialah menjadi penenun yang khususnya wanita, dan menjadi penjual gorengan keliling. Mesti hasil yang diperoleh mereka tidak sebesar hasil pokok kepala rumahtangganya, akan tetapi setidaknya dengan 
mereka bekerja ada pemasukan untuk mencukupi kebutuhan anggota keluargaanya. Setidaknya pekerjaan yang dilakukan oleh anggota keluarga lain seperti suami dan anak merupakan strategi rumahtangga penenun dalam mencukupi kebutuhan dan kekurangan yang dideritanya sehingga mereka tidak menjadi miskin.

\section{Jaringan Sosial}

Jaringan sosial yang terbentuk karena adanya peran modal sosial antara masyarakat lainnya, sehingga membentuk pendekatan atara masyarakat satu dengan masyarakat yang lain. Pendekatan antara warga lain merupana modal dari ibu penenun dan sangatlah membantu ibu penenun khususnya pada keluarga penenun, kesulitan dan kekurangan yang sering menghampiri rumahtangga penenun menjadikan keluarga penenun. tidak bisa lepas dari hutang. Baiknya jaringan sosial dapat meningkatkan status ekonomi dan menjamin keberlangsungan keluarga.

Kebutuhan yang mendesak dan harus tercukupi oleh keluarga penenun yang terkadang menjadi salah satu alasan kuat untuk berhutang ke dalam salah satu kekeluarga, tetangga, penyedia bahan baku ataupun terhadap pembeli sarung sekalipun. Oleh sebab itu jaringan sosial dapat mempermudah ibu penenun guna berinteraksi maupun saling tolong menolong satu sama lain. Strategi jaringan sosial inilah yang dilakukan keluarga penenun guna mencukupi kekurangan yang dihadapinya dengan cara meminjam uang atau berhutang.

Hutang merupakan suatu strategi yang sudah lumrah dilakukan oleh rumahtangga penenun untuk mencukupi kebutuhannya. Kebutuhan yang sangat mendesak dan ketika tidak mempunyai uang maka hal yang dilakukan ialah menghutang, oleh sebab itu menghutang dapat juga dikatakan sebagai budaya. Ibu penenun di Desa Lapolea biasanya berhutang pada salah satu penyedia bahan dan terhadap pembeli sarung. Seperti yang diungkapkan salah satu informan yang bernama ibu Wa Darliati 35 tahun, menyatakan bahwa:

"Menghutang adalah cara terakhir yang saya lakukan apabila saya benar- benar memerlukan dan mengalami kondisi yang sangat mendesak. Saya juga tidak asal menghutang, apabila saya punya tenunan yang sudah jadi dan sudah dijual maka saya langsung bayar'( Tanggal 20 April 2018).

Dari hasil wawancara di atas dapat disimpulkan bahwa mengutang adalah bukan hal yang baru bagi ibu rumah tangga. Mereka mengutang hanya dalam keadaan mendesak seperti ada kebutuhan yang memerlukan uang banyak. Hal senada juga dikatakan oleh seorang informan yang bernama ibu Wa Tia 47 tahun, menyatakan bahwa:

"Yang namanya manusia tidaklah bisa terlepas dari masalah keuangan apa lagi seperti saya yang hanya berprofesi menjadi penenun hasil tidak seberapa kebutuhan semakin hari semakin meningkat. Kebutuhan yang harus dipenuhi dan kadang mendadak seperti pembiayaan kuliah anak saya, dan tidak ada modal untuk membeli bahan tenunan menjadikan saya harus berhutang kepada pembeli sarung, terhadap kelurga juga untuk dapat memenuhi kebutuhan tersebut dan kepada si penyedia bahan tenunans. Oleh karena itu berhutanglah jalan satusatunya dan setelah saya mendapatkan hasil tenunan yang siap untuk dijual maka saya akan membayar hutang saya."( Tanggal 17 April 2018).

Hutang yang mereka lakukan pun tidaklah sembarang hutang. Mereka menghutang sebagian besar untuk memperbesar usaha seperti membeli bahan untuk perlengkapan menenun dan 
mmenghutang diakibatkan karena kebutuhan mendadak. Berhutang bukanlah hal yang sering atau terus menerus dilakukan oleh keluarga penenun ketika kekurangan yang menyebabkan kemiskinan menghampirinya. Akan tetapi hal tersebut dilakukan apabila keluarga penenun benar-benar membutuhkan bantuan yang sangat mendesak. Ibu penenun juga tidak mau ketergantungan dengan berhutang apabila kekurangan dalam mencukupi kebutuhannya. Oleh karena itu mereka lebih bekerja dengan giat dan ketika memperoleh hasil yang dirasa cukup mereka akan menyisihkan uangnya untuk ditabung. Apabila sewaktu-waktu mengalami keperluan yang mendadak dan mendesak uang tersebut dapat digunakan.

\section{Arisan}

Arisan merupakan hal yang penting bagi masyarakat selain arisan juga sebagai tempat menabung, juga sebagai tempat mengakrabkan diri dengan tetangga yang lain, ini sebabnya arisan termasuk kedalam strategi social yang didapatkan untuk bertahan hidup. Untuk bertahan hidup ibu penenun memanfaatkan kedekatannya bersama ibu-ibu lainnya, dengan membuat kelompok arisan bersama-sama ibu-ibu lainnya. Tujuannya diadakan kelompok arisan tersebut adalah untuk menabung secara kolektif dalam memperoleh modal tambahan yang dapat digunakan untuk membeli bahan-bahan tenunan serta kebutuhan keluarga. Seperti yang diungkapkan oleh ibu Wa Ode Kolo 48 tahun menyatakan bahwa:

"mengikuti arisan salah satu kegiatan saya dan ibu-ibu lainnya. Dengan ini kami saling bisa tukar informasi seputar bisnis yang kami jalani dan kabar masing ibu-ibu yang mengikuti arisan. Selain itu kami bisa menabung untuk menambah modal untuk mengembangkan usaha kami”(Tanggal 17 April 2018).

Hasil penelitian ini memperlihatkan bahwa arisan merupakan salah satu kegiatan ibu penenun yang dimana mereka bisa saling tukar informasi dan pendapat. Tidak hanya bertukar fikiran dan informasi akan tetapi mereka bisa menabung tanpa harus menabung di Bank. Pernyataan tersebut senada dengan seorang informan yang bernama ibu Wa Sanaria 39 tahun, mengatakan bahwa:

"Dengan adanya kelompok arisan ini saya bisa menabung uangku untuk tambahan modal usaha saya dan untuk persiapan ketika ada kebutuhan mendesak bagi anggota keluarga kami. Adapun jumlah ibu yang telah mengikuti arisan yaitu 15 orang/kelompok"(Tanggal 17 April 2018).

Dari hasil waawancara di atas dapat disimpulkan bahwa Arisan merupakan salah satu strategi bagi ibu penenun yang ada di desa Lapolea. Dengan adanya arisan ibu ibu penenun bisa mengumpulakan uang untuk pengembangan usaha mereka serta mengantisipasi kebutuhan keluarga yang tak terduga.

\section{PENUTUP}

Berdasarkan hasil penelitian mengenai strategi ibu rumah tangga penenun dalam upaya meningkatkan pendapatan keluarga ialah bahwa pendapatan ibu penenun yang diperoleh tidaklah pasti. Ketidakpastian dalam pendapatan ibu penenun dipengaruhi oleh 2 faktor. Faktor yang pertama kurangnya bahan. Faktor kedua ialah modal dan kondisi fisik penenun. Ketidakpastian 
pendapatan pendapatan menyebabkan kurang ketercukupan kebutuhan yang harus dipenuhi oleh seluruh anggota keluarga penenun, maka dapat disimpulkan bahwa dengan penghasilan yang diperoleh dari menenun hanya dapat mencukupi kebutuhan-kebutuhan primer saja, sedangkan tidak dapat menukupi kebutuhan sekunder. Rendahnya sumber daya manusia penenun yang dicirikan dengan rendahnya tingkat pendidikan keluarga penenun menyebabkan susahnya penenun untuk mengakses peluang-peluang kerja yang tersedia, khususnya peluang kerja di luar sektor peenunan.

Untuk dapat mencukupi kebutuhan primer dan sekunder, penenunan dan anggota keluarga yang lain melakukan beberapa strategi untuk dapat memenuhi kebutuhan yang harus terpenuhi. Strategi yang dilakukan meliputi strategi internal dan eksternal. Strategi internal meliputi: 1) Deverifikasi pekerjaan, strategi ini dilakukan apabila hasil yang diperoleh tidak menentu /ketidak pastian hasil yang diperoleh. Oleh sebab itu para ibu penenun melakukan pengkombinasian pekerjaan guna memperoleh penghasilan tambahan. Dimana para ibu penenun tidak bertumpuan pada satu pekerjaan tetapi mereka mencari pekerjaan lain selain menenun yang berguna untuk mencukupi kebutuhan keluarganya seperti berkebun dan menjadi penjual gorengan serta menjual kue keliling. 2) Peran anggota keluarga, salah satu strategi untuk menjaga kelangsungan hidup keluarga yaitu dengan memanfaatkan peran anggota keluarga (suami dan anak) dalam menambah penghasilan keluarga. 3) Jaringan sosial merupakan salah satu strategi dalam menghadapi kemiskinan dengan cara memanfaatkan masyarakat sekitarnya. Jaringan sosial inilah yang dilakukan ibu penenun guna mencukupi kebutuhan keluarga serta mencukupi kekurangan modal untuk membeli bahan-bahan tenunan dengan cara berhutang kepada keluarga, tetangga, penyedia bahan baku dan teman bisnis. 4) Arisan merupakan salah satu strategi yang dilakukan oleh ibu-ibu penenun guna mengumpulkan modal demi pengembangan usaha tenunan serta mengantisipasi kebutuhan keluarga yang tak terduga.

\section{DAFTAR PUSTAKA}

Adi, Isbandi Rukminto. 2015. Kesejahteraan Sosial. Jakarta: Raja Grafindo Persada

Arikunto, S. 2006. Prosedur Penelitian: Suatu Pendekatan Praktik. Jakarta: Rineka Cipta

BKKBN. 1995. Pendidikan Kesejahteraan Keluarga. Jakarta: BKKBN.

Chambers, Robert. (1987). Rural development-putting the last firs. New York: Longman Scientific and Technical.

Effendy, Onong Uchjana. 2007. Ilmu Komunikasi (Teori dan Praktek). Bandung: PT. Remaja Rosdakarya.

Fatimah, Titin. 2016. Profil Ekonomi Rumah Tangga Supir Angkutan Antar. Kota Pekanbaru Bangkinang . JOM FISIP Vol.3 No.1.

Friedman. 2004. Keperawatan Keluarga. Jakarta. EGC.

Hadi, Sutrisno. 2004. Penelitian Research. Yogyakarta: BPFE.

Kartia, W. 2016. Peran perempuan penenun kain mandar (panette) terhadap kesejahteraan keluarga. Makassar. Fakultas Dakwah Dan Komunikasi Uin Alauddin Makassar

Kusnadi. 2000. Strategi Adaptasi dan Jaringan Sosial. Bandung : Humoniora 
Kusnadi. 2002. Konflik Sosial Nelayan Kemiskinan dan Perebutan Sumber Daya Alam. Yogyakarta: LKIS

Kristianti, Farida Titik. 2014. Pengujian Variabel Makro Ekonomi Terhadap Jakarta Islamic Index. Bandung: Jurnal Keuangan dan Perbankan, Vol. 17, No. 1.

Moleong Lexi J. 2004. Metodologi Penelitian Kualitatif. Bandung: Remaja Rosdakarya.

Mugni, Abdul. 2006. "Strategi Rumah tangga Nelayan dalam Mengatasi Kemiskinan". Skripsi. Bogor: Institut Pertanian Bogor.

Myrdal, G. (1968). Asian Drama, An Inquiry into the Poverty of Nations, Vol. 3, Middlesex, England: The Penguin Books.

Neuman, W.L. 2007. basic of social Research: Qualitive and Quantitative Approach, Boston: Pearson Education, Inc

Sugiyono. 2005. Metode Penelitian Administrasi. Bandung: Alfabeta

Suharto, E . 2009. Kemiskinan dan Perlindungan Sosial di Indonesia. Bandung: Alfabeta

Suharto, Edi. 2005. Membangun Masyarakat Memberdayakan Rakyat, Bandung : Refika Aditama.

Suharto, E. 2009. Kemiskinan dan Perlindungan Sosial di Indonesia. Bandung: Alfabeta. 